\title{
LITTER-RAKING FORESTS IN SE SLOVENIA AND IN CROATIA
}

\author{
Urban ŠILC*, Andraž ČARNI*, Petra KOŠIR*, \\ Aleksander MARINŠEK* \& Igor ZELNIK*
}

\begin{abstract}
The standard Braun-Blanquet method was used for sampling litter-raking vegetation in southeastern Slovenia (Suha krajina, Bela krajina, Kočevsko) and in the border region in Croatia. Relevés were classified with the TWINSPAN program and two associations were separated: Pteridio-Betuletum Trinajstić et Šugar ex Rauš et Matić 1994 and Molinio-Quercetum Šugar 1972. Both communities are the result of intensive litter collecting (and other human impacts). The first one thrives on carbonate bedrock, while the second is limited on silicate bedrock, as is reflected in its specific floristic composition. Due to abandonment of litter collecting these stands are in progressive successional development, and typical variants are becoming rare and endangered.

Keywords: litter-raking, phytosociology, Molinio-Quercetum, Pteridio-Betuletum.

\section{Izvleček}

S standardno Braun-Blanquetovo metodo smo vzorčili steljniško vegetacijo vjugovzhodni Sloveniji (Suha krajina, Bela krajina, Kočevsko) in na mejnem območju s Hrvaško. Popisno gradivo smo klasificirali s programom TWINSPAN in ločili dve asociaciji: Pteridio-Betuletum Trinajstić et Sugar ex Rauš et Matić 1994 in Molinio-Quercetum Šugar 1972. Obe združbi sta nastali zaradi intenzivnega steljarjenja. Prva uspeva na karbonatni podlagi, druga je vezana na silikatne kamnine, kar se odraža v floristični sestavi. Zaradi opuščanja steljarjenja sta obe združbi podvrženi progresivnemu sukcesijskemu razvoju in sta v tipični obliki vedno bolj redki in ogroženi. Ključne besede: fitosociologija, Molinio-Quercetum, Pteridio-Betuletum, steljarjenje.
\end{abstract}

\section{INTRODUCTION}

Grazing on land for common use, and later litter collecting was very widespread in southeast Slovenia. In Central Europe it is known that farmers had collected litter for dunging their fields since the Iron age (Ellenberg 1996). Intensive litter-raking started at the end of the $18^{\text {th }}$ century and became widely spread in the middle of the $19^{\text {th }}$ century, when farming changed from free grazing to stockbreeding in stables. In Bela krajina, due to intensive human impact, an open cultural landscape was established at c. 900 cal. BP (Andrič 2007), but the need for litter changed the landscape drastically. As in western Europe heathlands became common, in southeastern Europe sparse birch woodlands appeared.
Litter-raking wood is a result of extensive management and is a degradation of forest vegetation and soil. Farmers used to cut bracken and heather, and also raked leaves of trees at the site. Occasionally they also cut some trees. Litter was not always transported to the farm, farmers put it on a heap with a single tree as a support, and the tree often died back after litter was removed. In this way they maintained a balance of sparse tree structure in the litter-raking wood and also the physiognomical appearance of this ecosystem (Štublar 1981).

Bracken (Pteridium aquilinum) is a characteristic plant (besides birch Betula pendula) in litter-raking wood communities. But its increased abundance within this ecosystem is recent, as the function of these sites was different in the past (Štublar 1981). As mentioned, these sites were grazed throughout

* Institute of Biology, Scientific Research Centre of the Slovenian Academy of Sciences and Arts, Novi trg 2, 1000 Ljubljana, Slovenia 
the season, and livestock destroyed the bracken that emerges in late April. Nowadays bracken is common and the local inhabitants name it as litter in the broader sense. Nevertheless bracken is not as problematic as in the United Kingdom (Mitchell et al. 1997, Marrs et al. 2000), where it is considered as a weed species. It causes problems for a wide range of land management options: it has a competitive effect on regenerating trees, invades different rare habitats, influences succesional pathways etc. Probably it is less problematic in Slovenia due to the low winter temperatures.

Vegetation scientists first noticed birch forests when vegetation surveys for cartographic purposes took place in the region, but syntaxon Pteridio-Betuletum Trinajstić et Šugar ex Rauš et Matić 1994 was merely used as a cartographic unit (Jovanović et al. 1986). Several authors studied birch stands in the framework of successional series towards vegetation climax (Wraber 1956, Piskernik 1962, Miklavžič 1965, Košir 1998). These forests were also considered in habitat typology as Illyrian birch woods (Robič 2002). Syntaxonomically these forests were validated only recently by Trinajstić (2004), while Quercus and Betula which dominated litter-raking forests on silicate bedrock were provisionally classified as Molinio-Quercetum Šugar 1972 (Kutnar 1996).

The aim of our study is syntaxonomically to classify litter-raking woods in southeastern Slovenia (and the neighbouring region in Croatia), that were neglected in syntaxonomical surveys and that are endangered in recent years due to the abandonment of traditional management.

\section{METHODS}

Vegetation was studied according to the Central European method (Braun-Blanquet 1964, West- hoff \& van der Maarel 1978). The nomenclature of plants is according to Martinčič \& al. (2007) and mosses according to Martinčič (2003). Relevés are stored in the TURBOVEG database (Hennekens \& Schaminée 2001).

Table editing and Ellenberg indicator values (Ellenberg et al. 1992) were calculated in JUICE 6.5 (Tichý 2002). Detrended Canonical Analysis (DCA) was made by CANOCO (ter Braak \& Šmilauer 2002). Species cover values were transformed into percentages, and TWINSPAN (Hill 1979) was used for classification of the whole dataset and delimitation of lower syntaxonomical units of Pteridio-Betuletum Trinajstić et Šugar ex Rauš et Matić 1994. Default values of cut levels $(0,5$ and 25) and 3 pseudospecies cut levels were used.

\section{STUDY AREA}

The study took place in southeastern Slovenia (Suha krajina, Bela krajina, Kočevsko) that belongs to the karstic region in SE Slovenia and in Croatia at the border region with Slovenia (between the villages of Pravutina and Mrzljaki) (Figure 1). The study area is classified within the Predinaric and Dinaric phytogeographical region. Also a sub-Pannonian influence is evident in Bela krajina (Wraber 1969). Characteristics of areas under consideration are presented in Table 1 (Perko \& Orožen Adamič 1998).

Potential natural vegetation of the study area is heterogeneous: Abio albae-Carpinetum Marinček 1994 in Bela krajina, Hacquetio-Fagetum Košir 1962 (incl. Hedero-Fagetum Košir 1994) in Suha krajina, Omphalodo-Fagetum (Tregubov 1957) Marinček et al. 1993 in Kočevsko and Blechno-Fagetum Horvat ex Marinček 1970 near the village of Ajbelj (Marinček \& Čarni 2002).

Table 1: Characteristics of researched areas.

Tabela 1: Značilnosti raziskovanih območij.

\begin{tabular}{|c|c|c|c|c|c|}
\hline & Bedrock & Soil & Climate & Precipitation & Temperature \\
\hline Suha krajina & $\begin{array}{l}\text { limestone (creta- } \\
\text { ceous and jurassic) }\end{array}$ & $\begin{array}{l}\text { Distric-Chromic } \\
\text { Cambisol }\end{array}$ & $\begin{array}{l}\text { moderate } \\
\text { continental }\end{array}$ & $1000-1300 \mathrm{~mm}$ & $\begin{array}{l}\text { average annual } 8{ }^{\circ} \mathrm{C} \\
\text { January }-2.4{ }^{\circ} \mathrm{C} \\
\text { July } 17.6{ }^{\circ} \mathrm{C}\end{array}$ \\
\hline $\begin{array}{l}\text { Bela krajina and area } \\
\text { between Pravutina and } \\
\text { Mrzljaki (Croatia) }\end{array}$ & $\begin{array}{l}\text { limestone and } \\
\text { dolomite }\end{array}$ & $\begin{array}{l}\text { eutric brown soils } \\
\text { and Terra Rossa }\end{array}$ & Pannonian & $1200-1300 \mathrm{~mm}$ & $\begin{array}{l}\text { average annual } \\
10.2^{\circ} \mathrm{C}\end{array}$ \\
\hline Kočevsko & $\begin{array}{l}\text { limestone (triassic) } \\
\text { and siliceous } \\
\text { conglomerate }\end{array}$ & $\begin{array}{l}\text { Distric-Chromic } \\
\text { Cambisol and } \\
\text { ranker }\end{array}$ & $\begin{array}{l}\text { moderate con- } \\
\text { tinental and } \\
\text { mountain }\end{array}$ & $1600 \mathrm{~mm}$ & $\begin{array}{l}\text { average annual } 7.9^{\circ} \mathrm{C} \\
\text { January }-2.8^{\circ} \mathrm{C} \\
\text { July } 17.9^{\circ} \mathrm{C} \\
\end{array}$ \\
\hline
\end{tabular}




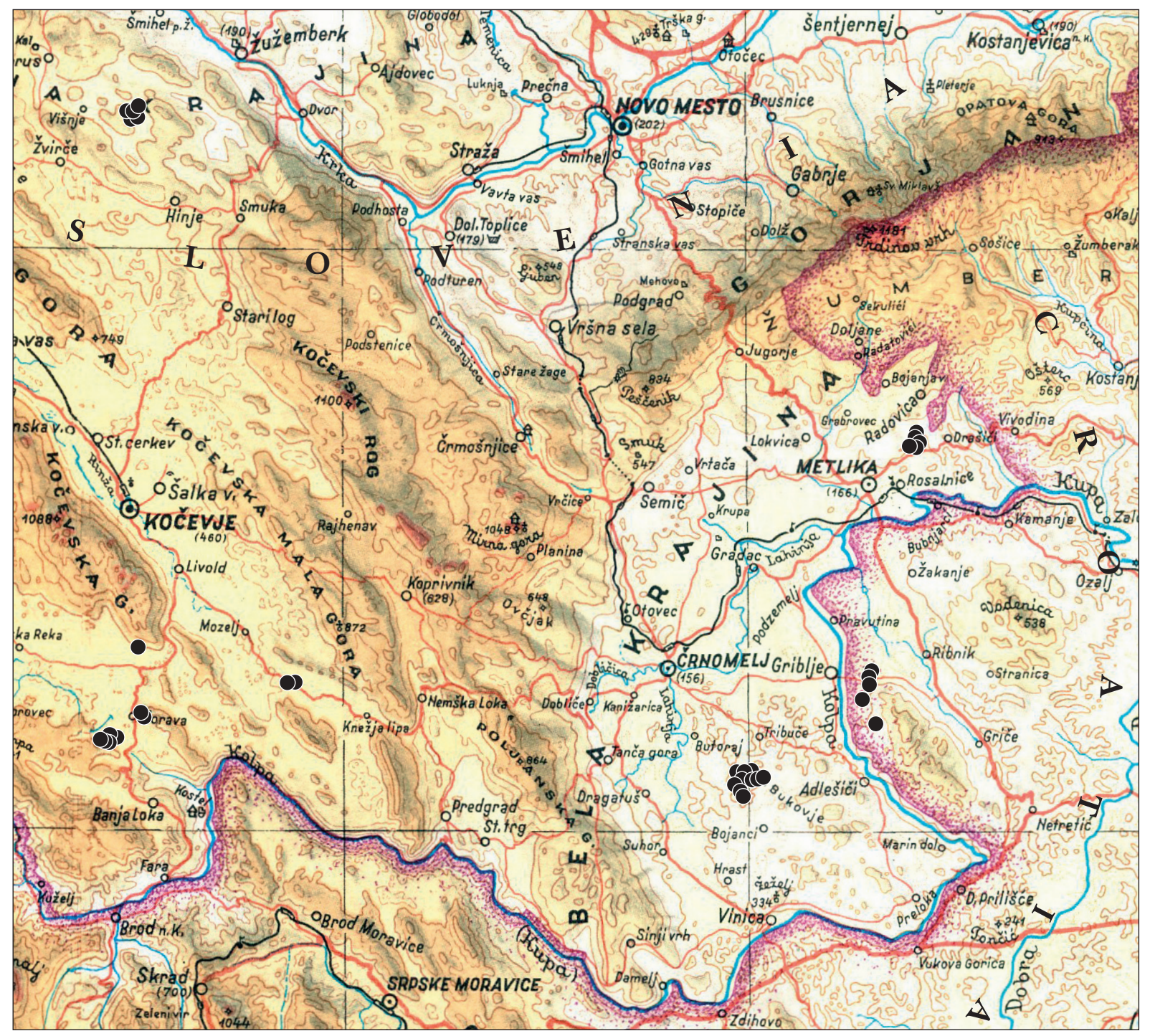

Figure 1: Study area. Slika 1: Raziskovano območje.

\section{RESULTS AND DISGUSSION}

TWINSPAN classification distinguished two groups of relevés corresponding to the two associations at first level. The first group comprises relevés belonging to the association Molinio-Quercetum Šugar 1972. The second group (comprising relevés belonging to the association Pteridio-Betuletum Trinajstić et Sugar ex Rauš et Matić 1994) was divided into another two levels according to the successional stages of the association.

Two distinctive groups of relevés were also detected by DCA ordination (Figure 3). The first group comprises relevés with dominant Betula pendula and the second with codominance of Betula

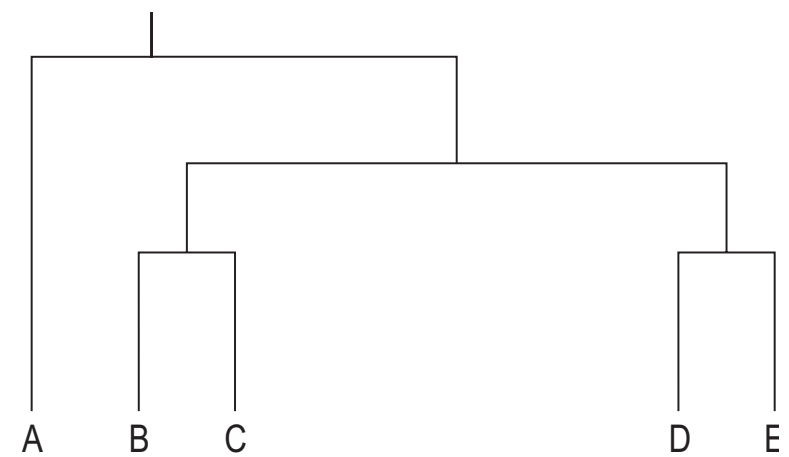

Figure 2: TWINPAN dendrogram. Table 4: A - relevés 31$35, \mathrm{~B}$ - relevés $1-4, \mathrm{C}$ - relevés 5 - 10, D - relevés $11-15$, E - relevés 16-30.

Slika 2: TWINPAN dendrogram. Tabela 4: A - popisi 31-35, B - popisi 1-4, C - popisi 5-10, D - popisi 11-15, E - popisi 16-30. 
pendula and Quercus petraea. According to floristic composition, the first group of relevés was classified as Pteridio-Betuletum Trinajstić et Šugar ex Rauš et Matić 1994, and the second group as Molinio-Quercetum Šugar 1972.

The results from the first two axes (Figure 3) show that samples of different forms of Pteridio-Betuletum Trinajstić et Šugar ex Rauš et Matić 1994 are grouped together; it is evident that there are differences in nutrients, reaction and light Ellenberg indicator values between older and younger successional stages. Successionally older stands group in the upper left part of the diagram and Ellenberg values indicate more nutrient rich and wet stands.

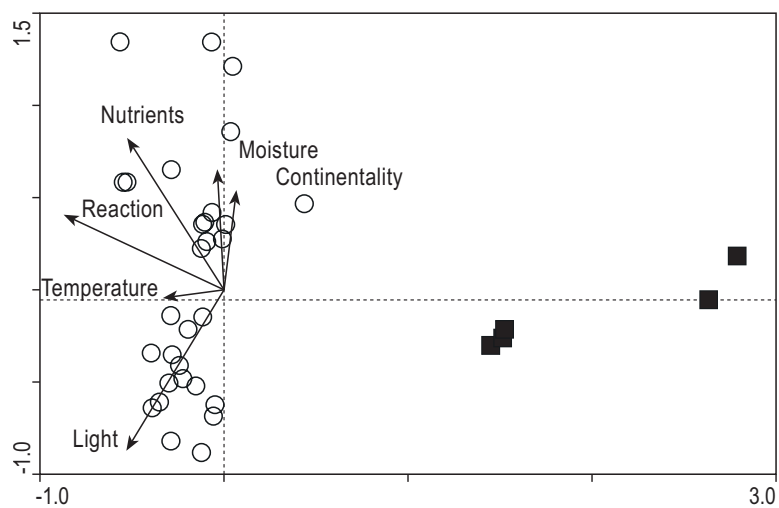

Figure 3: DCA analysis of floristic composition. Ellenberg indicator values are passively projected onto the diagram. Circle-Pteridio-Betuletum Trinajstić et Šugar ex Rauš et Matić 1994, square-Molinio-Quercetum Šugar 1972.

Slika 3: DCA analiza floristične sestave. Ellenbergove indikacijske vrednosti so pasivno projicirane na ordinacijski diagram. Krog-Pteridio-Betuletum Trinajstić et Šugar ex Rauš et Matić 1994, kvadrat-Molinio-Quercetum Šugar 1972.

Table 2: Ellenberg indicator values, calculated as mean unweighted value.

Tabela 2: Ellenbergove indikatorske vrednosti izračunane kot netehtano povprečje.

\begin{tabular}{|c|c|c|c|c|c|c|}
\hline & $\underset{\overrightarrow{0}}{\overrightarrow{0}}$ & 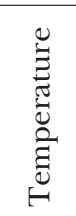 & 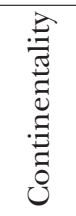 & 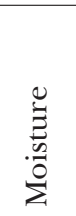 & 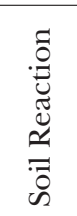 & 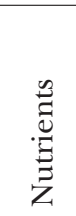 \\
\hline $\begin{array}{l}\text { Pteridio- } \\
\text { Betuletum }\end{array}$ & 6.32 & 5.36 & 3.74 & 4.82 & 5.04 & 3.47 \\
\hline $\begin{array}{l}\text { Molinio- } \\
\text { Ouercetum }\end{array}$ & 6.07 & 5.07 & 3.79 & 4.73 & 3.28 & 2.79 \\
\hline
\end{tabular}

Ecological indicator values (Table 2) show that both communities are found on acid sites and are poor in nutrients. There is an evident difference in some ecological conditions between both associations; Molinio-Quercetum Šugar 1972 is found on more acidophilic and more nutrient poor sites.

\section{Pteridio-Betuletum Trinajstić et Šugar ex Rauš et} Matić 1994

Table 4: 1-30

\section{Ecological conditions}

The community thrives on limestone bedrock. Soils are degraded by raking of litter, mowing, grazing, removal of organic matter, and sometimes even fire. Soils are podzols. Soil characteristics are presented in Table 3. In recent times litter is being less used as bedding for animals, and sites are mown once a year or even less often, while in the past they were regularly grazed throughout the vegetation period. Litter is removed from the site and this leads to depletion of soils and acidification.

Table 3: Soil characteristics in upper $10 \mathrm{~cm}$ layer in relevés from Drašiči (Čarni et al. 2007).

Tabela 3: Značilnosti tal $\mathrm{v}$ zgornjih $10 \mathrm{~cm} \mathrm{v}$ popisih iz Drašičev (Čarni et al. 2007).

\begin{tabular}{ll}
\hline $\mathrm{pH}$ & $4.18 \pm 0.08$ \\
$\mathrm{P}_{2} \mathrm{O}_{4}$ & $1.08 \pm 0.24$ \\
$\mathrm{~K}_{2} \mathrm{O}$ & $14.56 \pm 2.89$ \\
Org. matter & $7.06 \pm 3.72$ \\
Org. C & $4.1 \pm 2.14$ \\
$\mathrm{C}: \mathrm{N}$ & 14.18 \\
$\mathrm{~N}$ & $0.28 \pm 0.03$ \\
$\mathrm{Ca}^{2+}$ & $1.6 \pm 0.61$ \\
$\mathrm{Mg}^{2+}$ & $0.51 \pm 0.18$ \\
$\mathrm{~K}^{+}$ & $0.31 \pm 0.07$ \\
$\mathrm{Na}^{+}$ & $0.06 \pm 0.01$ \\
$\mathrm{H}^{+}$ & $2.5 \pm 0.38$ \\
\hline
\end{tabular}

\section{Floristic composition}

Species richness in stands ranges from 25 to 63 species per $100 \mathrm{~m}^{2}$, a plot with 38 species on average (Table 4).

Diagnostic species are Betula pendula in the tree layer and Pteridium aquilinum in the herb layer that also dominates the stands, although Trinajstić (2004) mentions only Betula pendula as characteristic species.

The tree layer is loose dense and rarely closed. Farmers when mowing for litter frequently cut 
down individual trees for fire wood, or else birch trees die as they are used for storing litter before

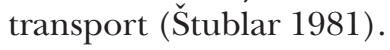

The shrub layer is poorly developed, because of mowing and the dense cover of Pteridium aquilinum. Only Frangula alnus is more abundant.

The herb layer is two layered. Pteridium aquilinum dominates in the upper layer and its dense cover and shadow hinders growth of other plants. It can grow up to $2 \mathrm{~m}$. The lower layer is rich in acidophilous species and species characteristic for poor soils (Calluno-Ulicetea $\mathrm{Br}$.-Bl. \& Tüxen ex Klika \& Hadač 1944 and Quercetalia roboris-petraeae Tüxen 1931).

\section{Lower syntaxonomic units}

The community shows great variability and was further divided with TWINSPAN analysis into variants that correspond also to successional stages.

- Carpinus betulus variant (Table 4, 1-4)

Stands of Carpinus betulus variant are successionally the most advanced stands that can be classified within association Pteridio-Betuletum Trinajstić et Šugar ex Rauš et Matić 1994. Tree species (e.g. Carpinus betulus, Quercus petraea) indicate development towards a climax community Abio albae-Carpinetum Marinček 1994. Also species of Rhamno-Prunetea Rivas Goday et Garb. 1961 are most abundant in this community, while species of Festuco-Brometea Br.-Bl. et R.Tx. 1943 and Calluno-Ulicetea Br.-Bl. \& Tüxen ex Klika \& Hadač 1944 are diminishing.

- Pinus sylvestris variant (Table 4, 5-10)

The stands are successionally older. Pinus sylvestris in the lower tree and shrub layer indicates a progressive stage of succession (Wraber 1956). Shrub species Frangula alnus differentiate later successional stages (Carpinus betulus and Pinus sylvestris variant) from typical ones.

- Carex flacca variant (Table 4, 11-15)

Within this variant we classify stands that thrive on sites of Omphalodo-Fagetum (Tregubov 1957) Marinček et al. 1993 as potential vegetation. Differential species are: Carex flacca and Salvia glutinosa. Brachypodium pinnatum agg. has higher cover. Species characteristic of order Quercetalia roboris-petraeae Tüxen 1931 and class Calluno-Ulicetea Br.-Bl. \& Tüxen ex Klika \& Hadač 1944 are poorly present. Stands are found at higher altitudes than for other variants (over $500 \mathrm{~m}$ a.s.l.).

- typical variant (Table 4, 16-30)
This variant is found in Bela krajina (Drašiči) and over the border in Croatia, on potential sites of Abio albae-Carpinetum Marinček 1994. Sites are regularly managed (mowed and litter raked) and represent the best preserved litter-raking woods in the region. Species of Quercetalia roborispetraeae Tüxen 1931 and Calluno-Ulicetea $\mathrm{Br}$.-Bl. \& Tüxen ex Klika \& Hadač 1944 are abundant, indicating an acidic and nutrient poor site.

Sites from Suha krajina (Visejec) thrive on potential sites of Hacquetio-Fagetum Košir 1962, and species Quercus cerris characterizes further successional developement in series HacquetioQuercetum cerris and Hacquetio-Fagetum (Marinček \& Šilc 1999).

\section{Syntaxonomy}

Birch forests were studied in several studies in the researched area and vicinity (Glišić 1950, Rauš \& Vukelić 1986, Vukelić \& Španjol 1990, Rauš \& Matić 1994, Košir 1998, Exner \& Willner 2004), but final syntaxonomical elaboration was made by Trinajstić (2004). Trinajstić classified Betula forests into two associations Pteridio-Betuletum Trinajstić et Šugar ex Rauš et Matić 1994, and Populo tremulaeBetuletum, but they are difficult to distinguish as there are only few character or differential species. This is also shown in Table 5 and in the ordination diagram (Figure 4).

Syntaxonomical classification of overexploited forest stands or semi natural communities that are in quasi-equilibrium is a special case in phytosociology. Even classification into rank of the association is problematic, as some authors claim that these are only short term successional stages. But regular management preserves constant species composition and quasi-equilibrium of the semi natural community. Management maintains the specific floristic composition of the community, and the syntaxonomical category management form (germ. Nutzungform or Agroform) can be used under the rank of the association (Willmans 1989). However, differences in floristic composition appear due to period length between management (or abandonment) and therefore could also be treated as successional stages.

Classification of birch forests is also difficult based strictly on floristic principles. Some authors have classified birch woods into class Calluno-Ulicetea Br.-Bl. \& Tüxen ex Klika \& Hadač 1944 together with heathlands (Wraber 1956). Structural 
characteristics of stands should be taken into consideration (Dierschke 1994) as well as the developed tree layer. Therefore, they should be classified into syntaxa comprising forest communities.

\section{Molinio-Quercetum Šugar 1972}

Table 4: 31-35

\section{Ecological conditions}

Stands thrive on silicate bedrock (Carboniferous and Permian sandstone, siltstone and claystone) (Kutnar 1996), the soil is Dystric Brown Soil (Kutnar \& Urbančič 2006). Ellenberg indicator values show most acidic and nutrient poor sites, even compared to stands of Pteridio-Betuletum Trinajstić et Šugar ex Rauš et Matić 1994 (Table 2). Stands thrive on slopes with southern apect and considerable inclination.

Kutnar (1996) reports several impacts that play a role in forming of this community, which according to Šugar (1973) is a permanent degradation stage of primary acidophilous beech forests. Beside unfavourable natural conditions degradation processes are due to litter-raking, game grazing and forest fires.

\section{Floristic composition}

Stands are species poor (18 species per $100 \mathrm{~m}^{2}$ on average). Characteristic species of the association according to Šugar (1972) are: Calamagrostis arundinacea, Hieracium racemosum and Molinia caerulea ssp. arundinacea. In researched stands only the latter was found, but Vaccinium myrtilus and Erica carnea could be also pointed out as diagnostic species.

Betula pendula and Quercus petraea dominate in the tree layer, although it has low cover.

Shrubs are poorly developed, not only due to management but also due to harsh ecological conditions. Only dominant tree species are regenerating successfully.

The herb layer is composed mainly of chamaephytic species: Erica carnea, Calluna vulgaris, Vaccinium myrtillus and codominant Molinia caerulea ssp. arundinacea. Other species are rare and they develop only in gaps between dense shrubby cover.

\section{Syntaxonomy}

Studies of similar stands have a long history in Slovenia and in neighbournig countries, therefore several classifications were proposed.
Tüxen described two similar associations Betulo-Quercetum roboris Tx. 1930 and Betulo-Quercetum petraeae Tx. 1937, but Härdtle et al. (1997) combined them into one wide association, that is still under critical revision.

Wallnöfer et al. (1993) classify similar stands in Austria as Deschampsio flexuosae-Quercetum sessiliflorae Firbas et Sigmond 1928. For Slovenia Košir (1994) mentions this association for southwestern hilly margins of Pannonia. Later Willner \& Grabherr (2007) revised the previous classification and introduced a new division of association with three syntaxa: Luzulo-Quercetum petraeae Hilitzer 1932, Betulo-Quercetum roboris Tx. 1930 and Genisto germanicae-Quercetum roboris Aich. 1933.

In Croatia, Trinajstić (2008) reports on the existence of several associations within a separate class Quercetea roboris-petraeae Br.-Bl. et R.Tx. 1943: Betulo-Quercetum petraeae Tx. 1937, Luzulo-Quercetum petreae (Hilitzer 1932) Passarge 1953, Hieracio racemosi-Quercetum petreae Vukelić1991, Betulo-Quercetum petraeae Tx. 1937, Molinio altissimae-Quercetum petraeae Šugar 1972.

In Slovenia, Košir (1994) classified acidophilous Quercus petrea forests in the SW part of the Pannonian region as Deschampsio flexuosae-Quercetum, that thrives on silicate bedrock on ranker soil type. It develops progressively into the asociation Deschampsio-Fagetum. Puncer \& Zupančič (1981) described association Melampyro vulgati-Quercetum, which is a degradation stage of the association Castaneo-Fagetum Marinček \& Zupančič 1995. Kutnar (1996) researched the vegetation of Veliki Mošenik and classifed stands into Molinio altissimae-Quecetum petraeae Šugar 1972, that develop as a degradation stage of the association Blechno-Fagetum Horvat ex Marinček 1970.

In Table 5 Betula pendula and Quercus petraea stands (and some other acidophilous Quercus forests) from Slovenia and Croatia in the synoptic table as originally classified by the authors are presented. Numerical analysis of the synoptic table is presented in Figure 4, but unfortunately some types were not published with analytical tables (Horvat 1962, Košir 1994) and were therefore omitted from analysis. Relevés separate along the second axis due to different bedrock. In the upper part of the diagram, stands on non-carbonate bedrock are concentrated (classified within Molinio-Quercetum Šugar 1972), while in the lower part are stands that thrive on carbonate sites (classified within PteridioBetuletum Trinajstić et Šugar ex Rauš et Matić 1994 and Betulo-Quercetum Šugar 1972). The first axis 
represents successional development, on the right side we find more developed stands towards less degraded communities.

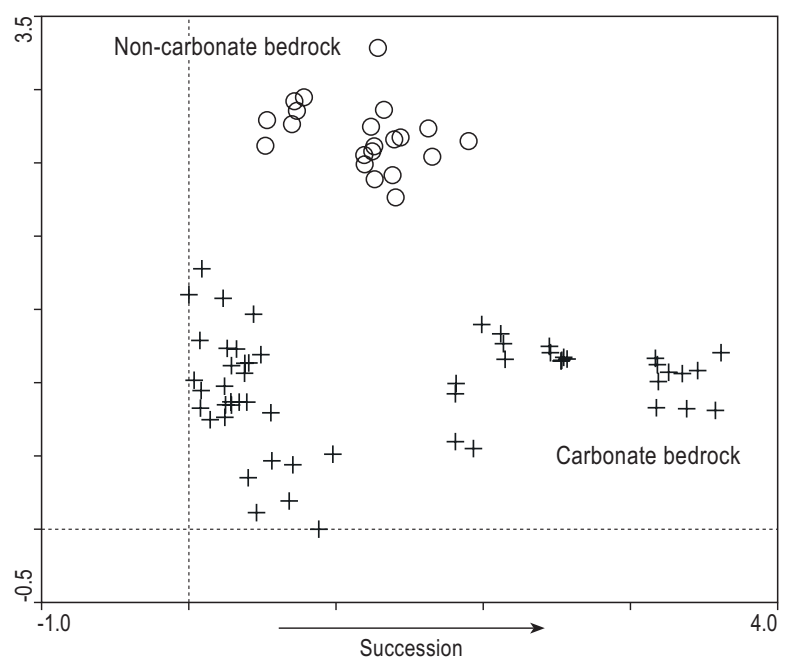

Figure 4: DCA ordination diagram of relevés from Table 5. Circle: Molinio-Quercetum (Šugar 1972, Šilc et al. hoc loco), cross: Pteridio-Betuletum (Vukelić \& Španjol 1990, Rauš \& Matić 1994, Trinajstić 2004, Šilc et al. hoc loco), Populo-Betuletum (Trinajstić 2004), Betulo-Quercetum (Rauš \& Vukelić 1986).

Slika 4: DCA ordinacijski diagram popisnega gradiva iz Tabele 5. Krog: Molinio-Quercetum (Šugar 1972, Šilc et al. hoc loco), križ: Pteridio-Betuletum (Vukelić \& Španjol 1990, Rauš \& Matić 1994, Trinajstić 2004, Šilc et al. hoc loco), Populo-Betuletum (Trinajstić 2004), Betulo-Quercetum (Rauš \& Vukelić 1986).

\section{CONCLUSION}

Both communities are endangered as farmers abandon regular litter collecting. Molinio-Quercetum Šugar 1972 is rare also because the non-carbonate type of bedrock is rare in this part of Slovenia. Stands of Pteridio-Betuletum Trinajstić et Šugar ex Rauš et Matić 1994 are left to succession and we can expect their development towards potential forest vegetation as these stands convert into hornbeam forest in 40 years (Čarni et al. 2007). Therefore some areas were protected as landscape parks and natural monuments, where measures of revitalisation were taken. Some of stands are also used for touristic purposes.

Also some plants protected by Supplement to the Decree on protected wildlife plant species (Official Gazette of the RS, No. 46/04, 110/04, 115/2007), are found in these communities: Cyclamen purpurascens, Dianthus barbatus, Helleborus dumetorum and Lycopodium clavatum.

\section{ACKNOWLEDGEMENT}

We are grateful to I. Sajko for making the map of localities, and to B. Šuštar for help in the field. Two reviewers made valuable improvement on an earlier version of the manuscript. Alan McConnellDuff helped to revise our English. The research was funded by grant L1-6517.

\section{APPENDIX}

Table number, locality, geographical coordinates, and date of relevés in Table 4:

1. Dragatuš, 518544, 41664, 23. 6. 2004; 2. Dragatuš, 518734, 41815, 23. 6. 2004; 3. Dragatuš, 518659, 41255, 23. 6. 2004; 4. Dragatuš, 518664, 41235, 23. 6. 2004; 5. Dragatuš, 518382, 41570, 23. 6. 2004; 6. Dragatuš, 519191, 41831, 7. 9. 2004; 7. Dragatuš, 519152, 41775, 7. 9. 2004; 8. Dragatuš, 518827, 42119, 7. 9. 2004; 9. Dragatuš, 518812, 42089, 7. 9. 2004; 10. Dragatuš, 519250, 41914, 7. 9. 2004; 11. Stalcerji, 490013, 48116, 1. 8. 2006; 12. Morava, 490262, 44889, 1. 8. 2006; 13. Morava, 490294, 44841, 1. 8. 2006; 14. Mozelj, 497319, 46437, 11. 8. 2006; 15. Mozelj, 497359, 46445, 11. 8. 2006; 16. Croatia, Kunići, 525102, 44465, 7. 7. 2004; 17. Drašiči, 527021, 57916, 1. 7. 2004; 18. Drašiči, 526816, 57712, 6. 7. 2004; 19. Croatia, Mošanci, 524459, 45622, 7. 7. 2004; 20. Drašiči, 527046, 57655, 7. 7. 2004; 21. Drašiči, 526993, 57846, 1. 7. 2004; 22. Croatia, 524793, 46328, 7. 7. 2004; 23. Drašiči, 527176, 57842, 7. 7. 2004; 24. Croatia, 524880, 46894, 7. 7. 2004; 25. Croatia, 524767, 46695, 7. 7. 2004; 26. Visejec, 489752, 73486, 21. 6. 2006; 27. Visejec, 489672, 73225, 5. 7. 2006; 28. Visejec, 489687, 73584, 4. 7. 2006; 29. Visejec, 489779, 73616, 4. 7. 2006; 30. Visejec, 489806, 73620, 4. 7. 2006; 31. Ajbelj, 488662, 43754, 1. 8. 2006; 32. Ajbelj, 488573, 43728, 1. 8. 2006; 33. Ajbelj, 488605, 43714, 1. 8. 2006; 34. Ajbelj, 488644, 43707, 1. 8. 2006; 35. Ajbelj, 488638, 43697, 1. 8. 2006.

\section{REFERENCES}

Andrič, M. 2007: Holocene vegetation development in Bela krajina (Slovenia) and the impact of first farmers on the landscape. Holocene 17 (6): 763-776. (DOI: 10.1177/0959683607080516)

Braun-Blanquet,J.1964:Pflanzensoziologie. Grundzüge der Vegetationskunde. Springer Verlag, Wien, 865 pp. 
Čarni, A., Košir, P., Marinšek, A., Šilc, U. \& Zelnik, I. 2007: Changes in structure, floristic composition and chemical soil properties in a succession of birch forests. Periodicum biologorum 109 (1): 13-20.

Dierschke, H. 1994: Pflanzensoziologie: Grundlage und Methoden. Ulmer, Stuttgart, 683 pp.

Ellenberg, H. 1996: Vegetation Mitteleuropas mit den Alpen. Ulmer Verlag, Stuttgart, 1095 pp.

Ellenberg, H., Weber, H. E., Düll, R., Wirth, V., Werner, W. \& Paulißen, D. 1992: Zeigerwerte von Pflanzen in Mitteleuropa. Erich Goltze, Göttingen, 258 pp.

Exner, A. \& Willner, W. 2004: New syntaxa of shrub and pioneer forest communities in Austria. Hacquetia 3 (1): 27-48.

Glišić, N. 1950: Fitocenološki pogledi na pošumljavanje šumskih požarišta. Godišnjak Biološkog Instituta Sarajevo 3 (1-2): 115-130.

Härdtle, W., Heinken, T., Pallas, J. \& Weiß, W. 1997: Synopsis der Pflanzengesellschaften Deutschlands, Querco-Fagetea (H5). Sommergrüne Laubwälder. Part 1. Quercion roboris. Bodensaure Eichenmischwälder. Göttingen, 51 pp.

Hennekens, S. M. \& Schaminée, J. H. J. 2001: TURBOVEG, a comprehensive data base management system for vegetation data. Journal of Vegetation Science 12 (4): 589-591.

Hill, M. O. 1979: TWINSPAN. A FORTRAN program for arranging multivariate data in an ordered two-way table by classification of the individuals and attributes. Ithaca, New York, Ecology \& systematics, Cornell University.

Horvat, I. 1962: Vegetacija plaina zapadne Hrvatske. JAZU, Zagreb, 179 pp.

Jovanović, B., Lakušić, R., Rizovski, R., Trinajstić, I. \& Zupančič, M. 1986: Prodromus phytocoenosum Jugoslaviae, ad mappam vegetationis m 1:200 000. Naučno veće vegetacijske karte Jugoslavije, Bribir-Ilok, 46 pp.

Košir, Ž. 1994: Ekološke in fitocenološke razmere v gorskem in hribovitem jugozahodnem obrobju Panonije. Ministrstvo za kmetijstvo in gozdarstvo, Ljubljana, 149 pp.

Košir, Ž. 1998: Breze v okolju gozdov smreke in jelke v Snežniškem pogorju. Gozdarski vestnik 56 (3): 131-148.

Kutnar, L. \& Urbančič, M. 2006: Vpliv rastiščnih in sestojnih razmer na pestrost tal in vegetacije $\mathrm{v}$ izbranih bukovih in jelovo-bukovih gozdovih na Kočevskem. Zbornik gozdarstva in lesarstva 80: 3-30.

Kutnar, L. 1996: Uporaba fotointerpretacije aero- posnetkov in GIS tehnik pri kartiranju ter proučevanje gozdne vegetacije. Gozdarski vestnik 54 (10): 502-510.

Maars, R. H., Le Duc, M. G., Mitchell, R. J., Goddard, D., Petterson, S. \& Pakeman, R. J. 2000: The Ecology of Bracken: its role in succession and implication for control. Annals of Botany 85 (Sup. B): 3-15. (DOI: 10.1006/anbo.1999.1054)

Marinček, L. \& Čarni, A. 2002: Komentar k vegetacijski karti gozdnih združb Slovenije v merilu 1:400 000. Založba ZRC, Biološki inštitut Jovana Hadžija ZRC SAZU, Ljubljana, 79 pp.

Marinček, L. \& Šilc, U. 1999: Association of Hacquetio epipactidis-Quercetum cerris in the Lož Valley in Slovenia. Wissenschaftliche Mitteilungen aus dem Niederösterreichischen Landesmuseum 12: 63-76.

Martinčič, A. 2003: Seznam listnatih mahov (Bryopsida) Slovenije. Hacquetia 2 (1): 91-166.

Martinčič, A., Wraber, T., Jogan, N., Podobnik, A., Ravnik, V., Turk, B., Vreš, B., Frajman, B., Strgulc-Krajšek, S., Trčak, B., Bačič, T., Fischer, M. A., Eler, K. \& Surina, B. 2007: Mala flora Slovenije: ključ za določanje praprotnic in semenk. Tehniška založba Slovenije, Ljubljana, $845 \mathrm{pp}$.

Miklavžič, J. 1965: Premena belokranjskih steljnikov v gozdove. Zbornik IGLG 4: 1-87.

Mitchell, R. J., Marrs, R. H., Le Duc, M. G. \& Auld, M. H. D. 1997: A study of succession on lowland heaths in Dorset, southern England: changes in vegetation and soil chemical properties. Journal of Applied Ecology 34: 1444-1462.

Perko, D. \& Orožen Adamič, M. (ed.) 1998: Slovenija: pokrajine in ljudje. Mladinska knjiga, Ljubljana, $735 \mathrm{pp}$.

Piskernik, M. 1962: Rastlinstvo in rastišča belokranjskih steljnikov. Ljubljana. Manuscript.

Puncer, I. \& Zupančič, M. 1981: Novi združbi gradna v Sloveniji (Melampyro vulgati-Quercetum petraeae ass. nova s.lat.). Scopolia 2: 1-47.

Rauš, Đ. \& Matić 1994: Istraživanje vegetacijskih i uzgojnih problema obične breze (Betula pendu$l a$ Roth) na području Požege i Slatine. Glasnik za šumarske pokuse 30: 337-360.

Rauš, Đ. \& Vukelić, J. 1986: Vegetacijske i strukturne osobine obične breze (Betula pendula Roth) na Psunju. Šumarski list 110 (5-6): 177-187.

Robič, D. 2002: Seznam in nomenklatura habitatnih tipov gozdov za njihovo vključitev v območja Natura 2000 v skladu s priloženo projektno nalogo. Mscr. 
Štublar, B. 1981: Steljarjenje v zasebnih belokranjskih gozdovih kot družbeno ekonomski problem. B.Sc. Graduation thesis, Department of Forestry, Biotechnical Faculty, University of Ljubljana, Ljubljana.

Šugar, I. 1972: Biljni svijet samoborskog gorja. PhD Thesis, University of Zagreb, Zagreb.

Šugar, I. 1973: Dvije nove zajednice u Samoborskom gorju. Acta Botanica Croatica 32: 197202.

ter Braak, J. F. C. \& Šmilauer, P. 2002: CANOCO Reference Manual and CanoDraw for Windows User's Guide to Canoco for Windows: Software for Canonical Community Ordination (version 4.5). Microcomputer Power (Ithaca, NY, USA), Ithaca, NY, USA, 500 pp.

Tichý, L. 2002: JUICE, software for vegetation classification. Journal of Vegetation Science 13: 451-453.

Trinajstić, I. 2004: Nomenklaturno-sintaksonomska analiza šuma obične breze (Betula pendula Roth) u Hrvatskoj. Šumarski list 78 (11-12): 627-632.

Trinajstić, I. 2008: Biljne zajednice Republike Hrvatske. Akademija šumarskih znanosti, Zagreb, 179 pp.
Vukelić, J. \& Španjol, Ž. 1990: Fitocenološki karakter čistih sastojina obične breze (Betula pendula Roth) u području panonskih šuma bukve i jele (Fagetum croaticum boreale abietetosum Horv.) na Papuku. Šumarski list 114: 357-368.

Wallnöffer, S., Mucina, L. \& Grabherr, G. 1993: Querco-Fagetea. In: Mucina, L., Grabherr, G. \& Wallnöffer, S. (ed.): Pflanzengesellschaften Österreichs-Wälder und Gebüsche. Gustav Fisher Verlag, Jena, Stuttgart, New York, pp. 85-236.

Westhoff, V. \& van der Maarel, E. 1978: The BraunBlanquet approach. In: Whittaker, R. H. (ed.): Ordination and Classification of Communities. Dr. W. Junk Publishers, The Hague, pp. 617727.

Willner, W. \& Grabherr, G. 2007: Die Wälder und Gebüsche Österreichs. Elsevier, München, 302 pp.

Wilmanns, O. 1989: Vergesellschaftung und Strategie-Typen von Pflanzen mitteleuropäischer Rebkulturen. Phytocoenologia 18 (1): 83-128.

Wraber, M. 1956: Gozdna in steljniška vegetacija Bele krajine. Biološki inštitut ZRC SAZU, Ljubljana. Manuscript.

Wraber, M. 1969: Pflanzengeographische Stellung und Gliederung Sloweniens. Vegetatio 17 (1-6): 176-199. 


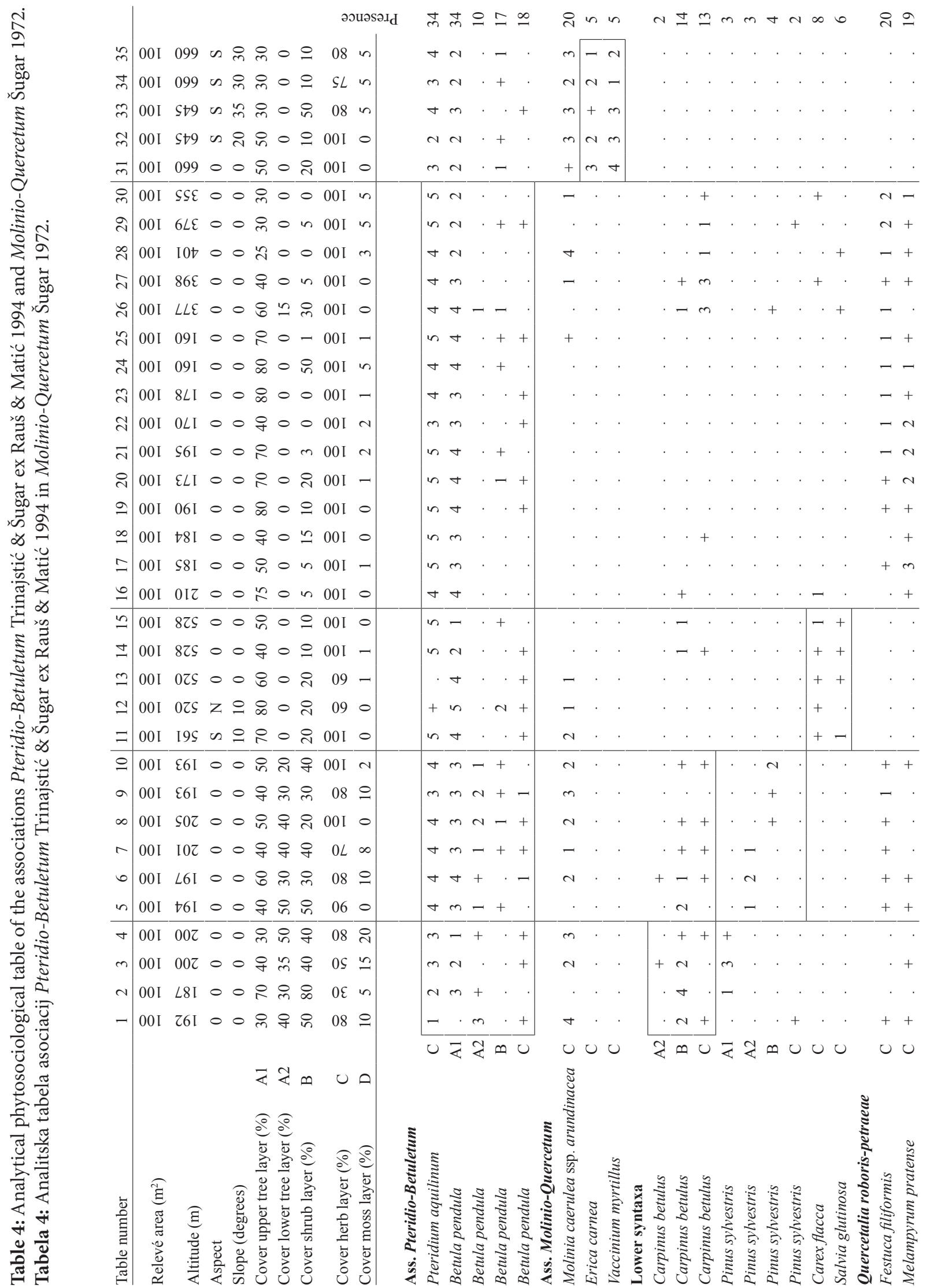




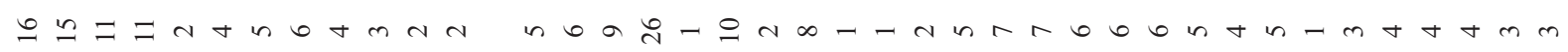
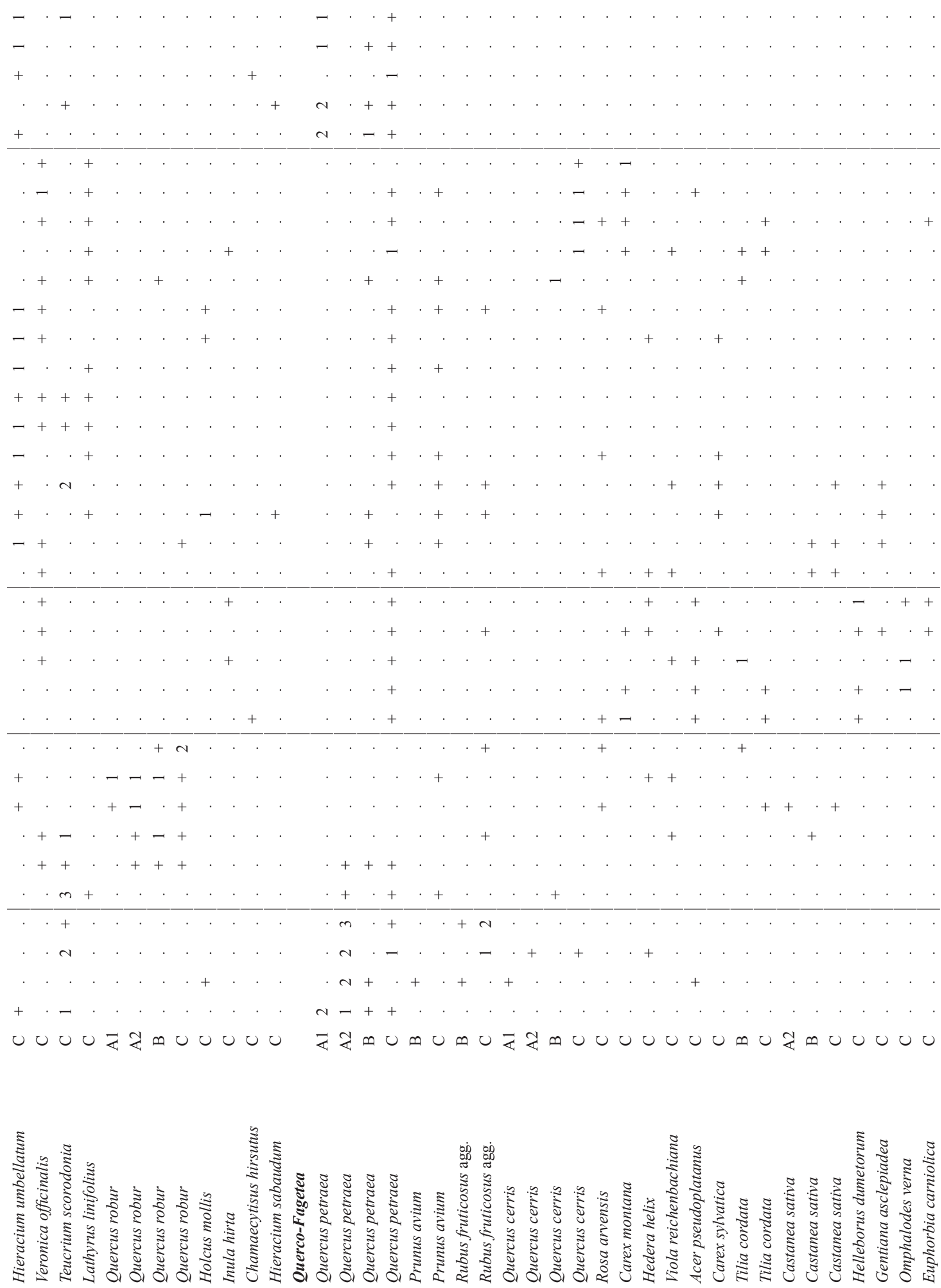


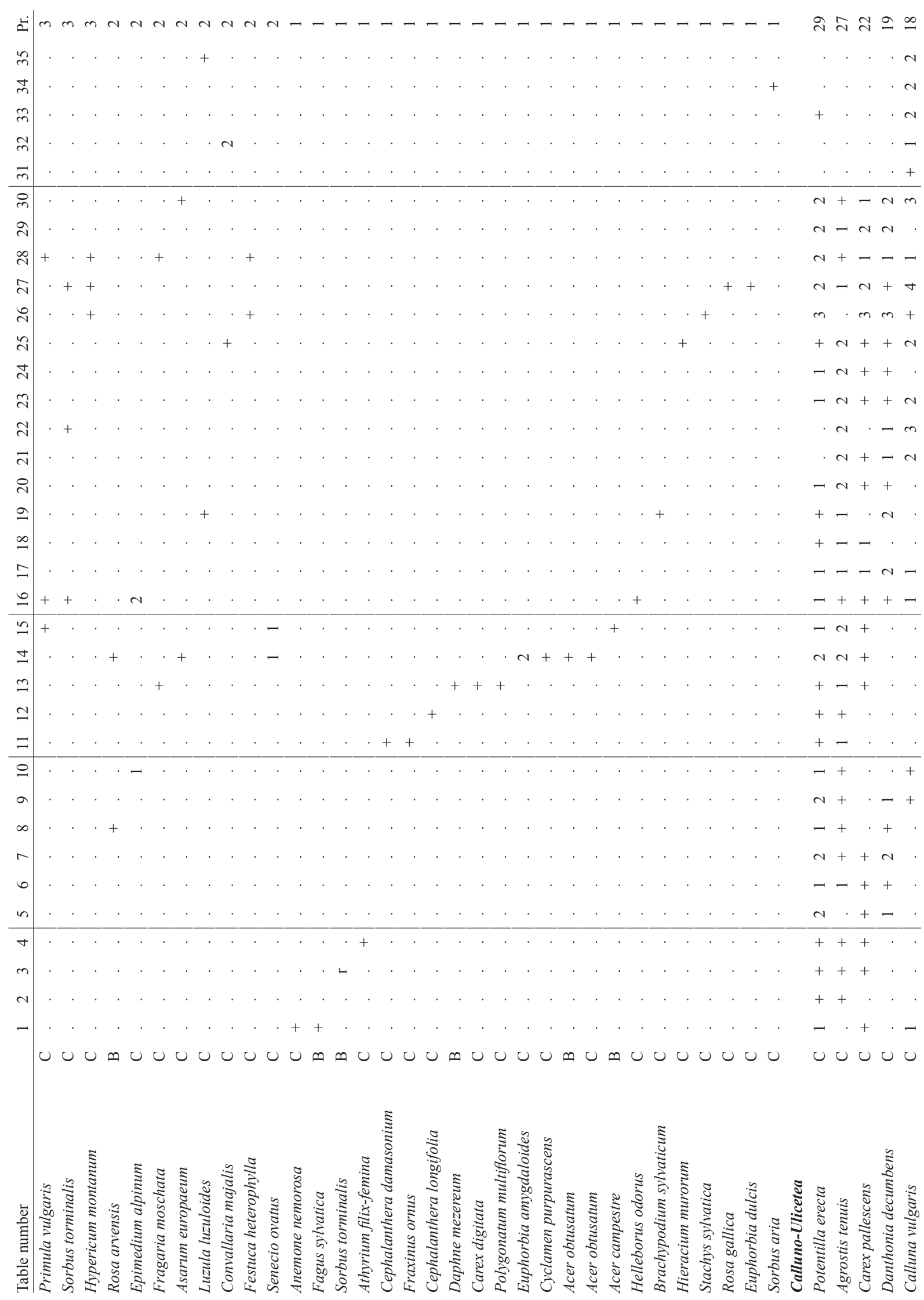




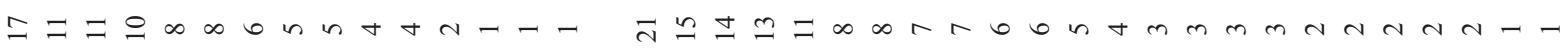
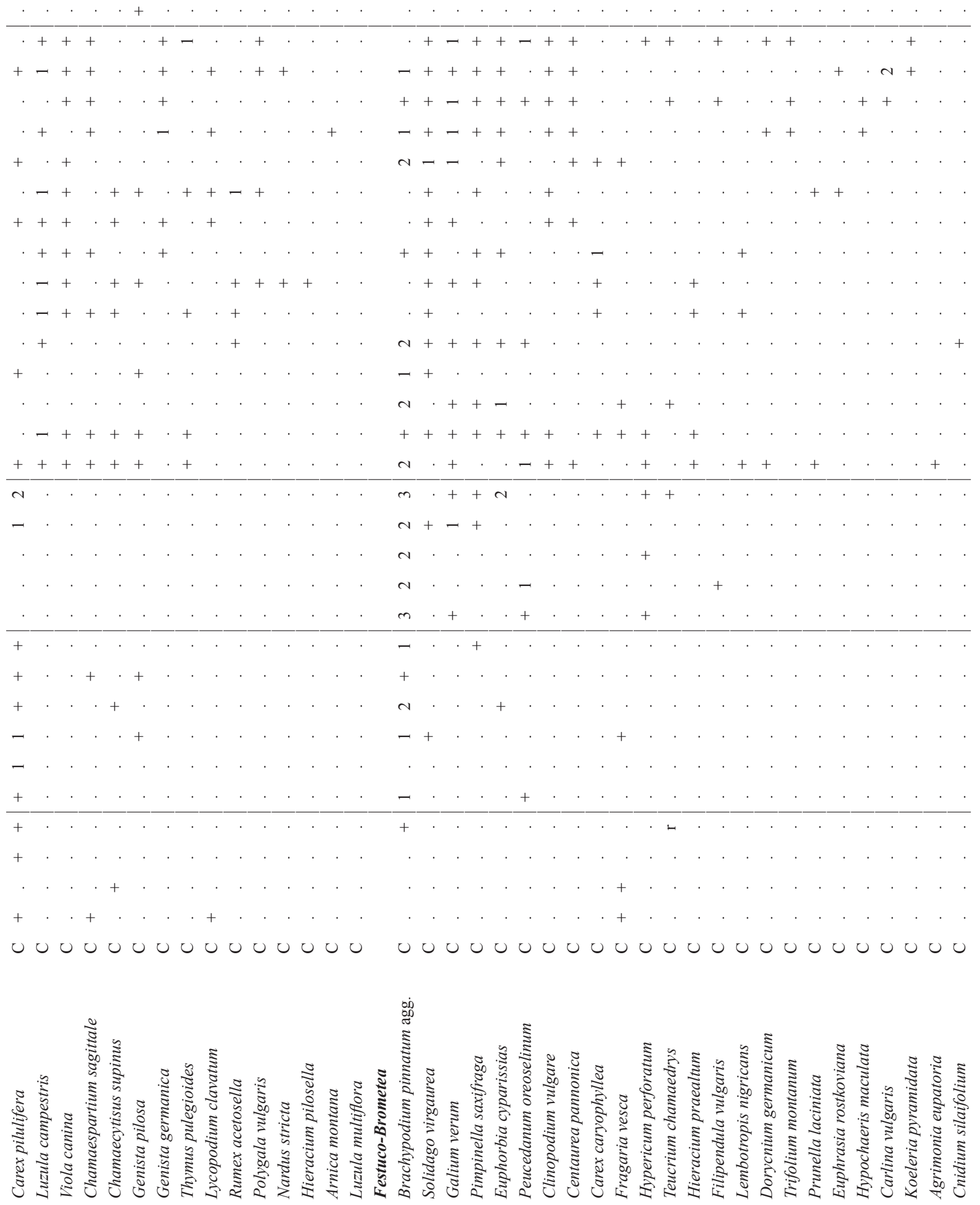


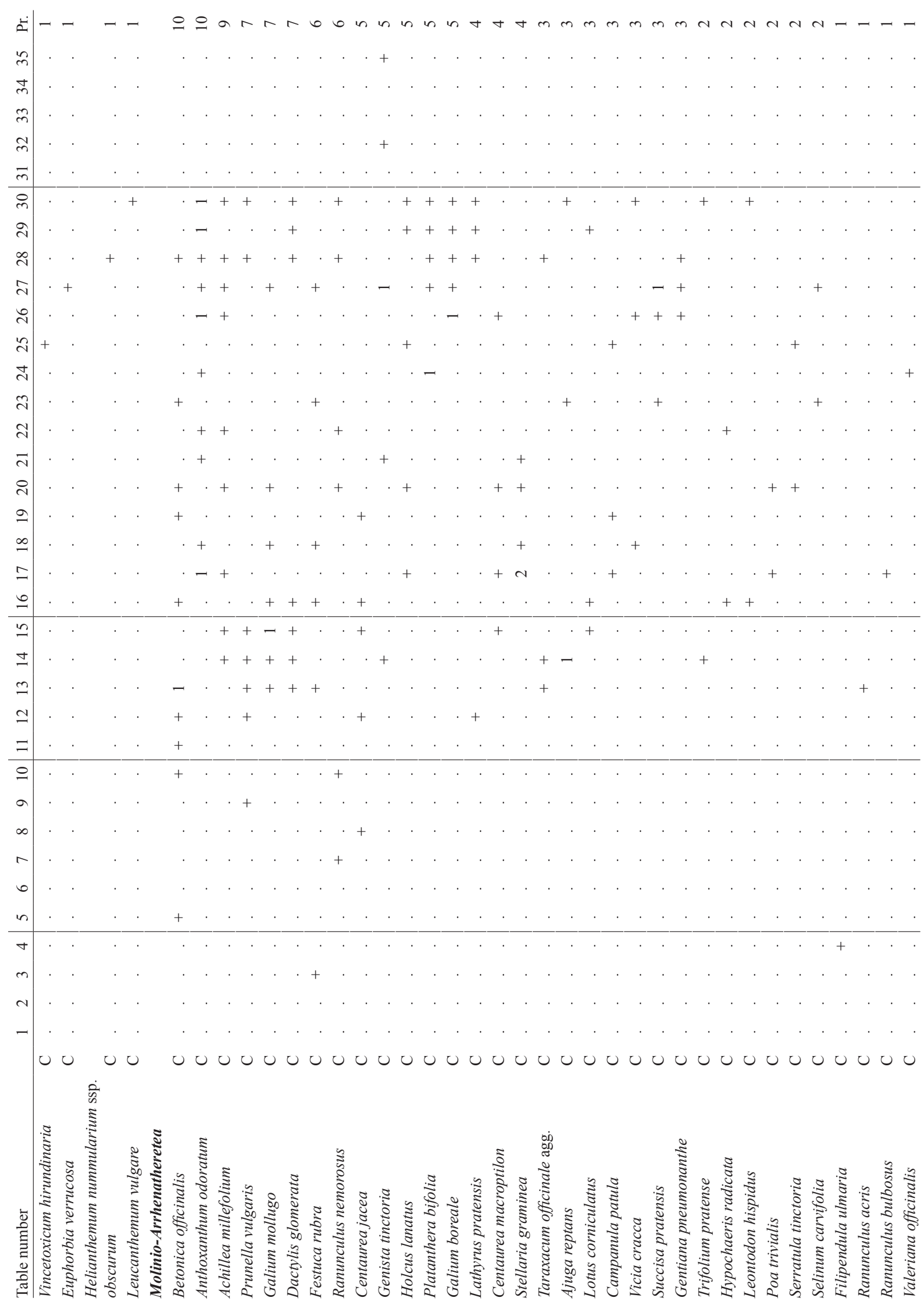




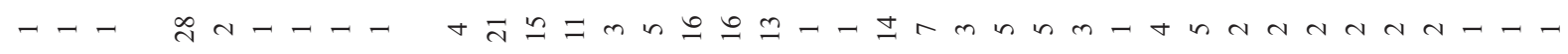
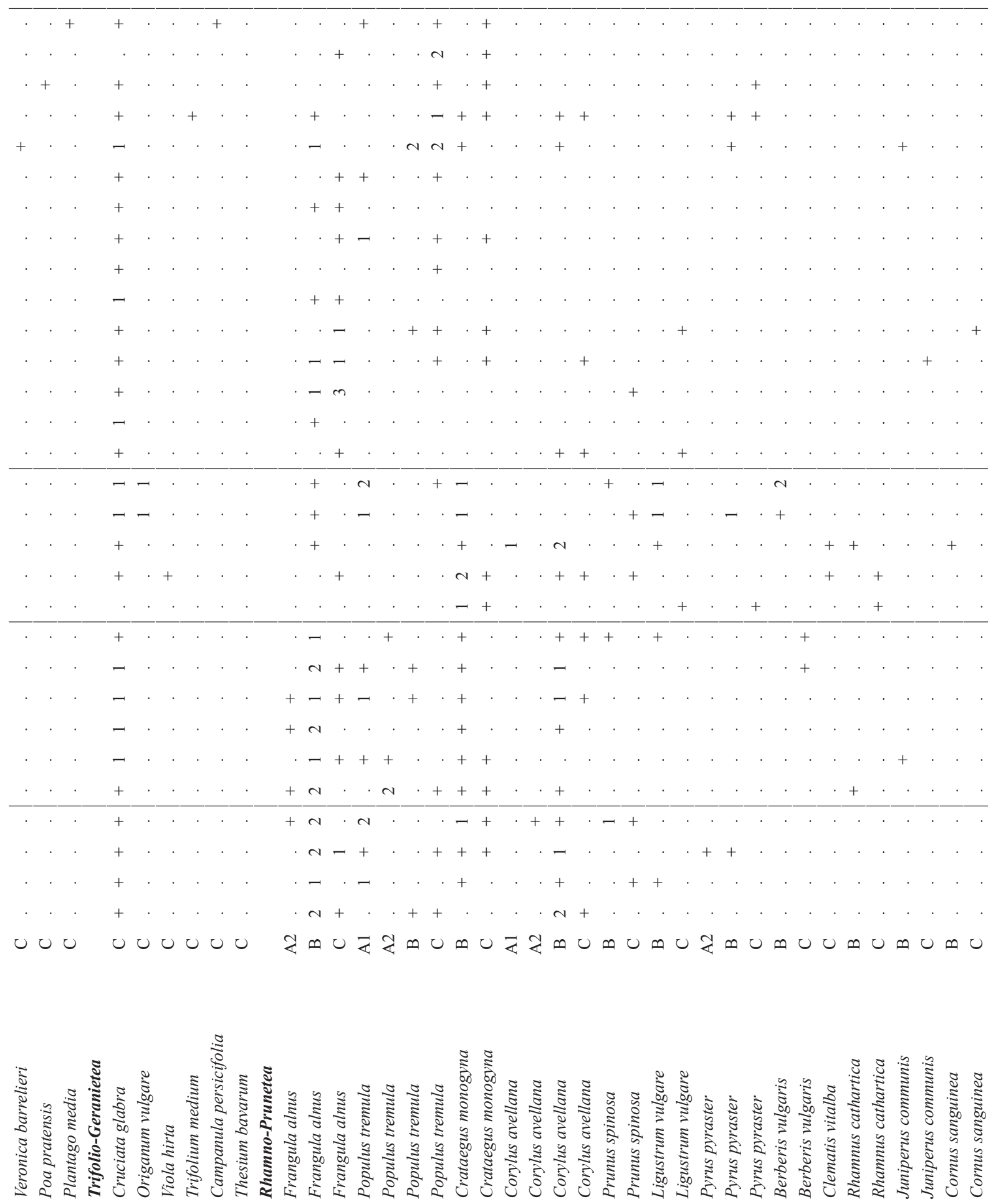


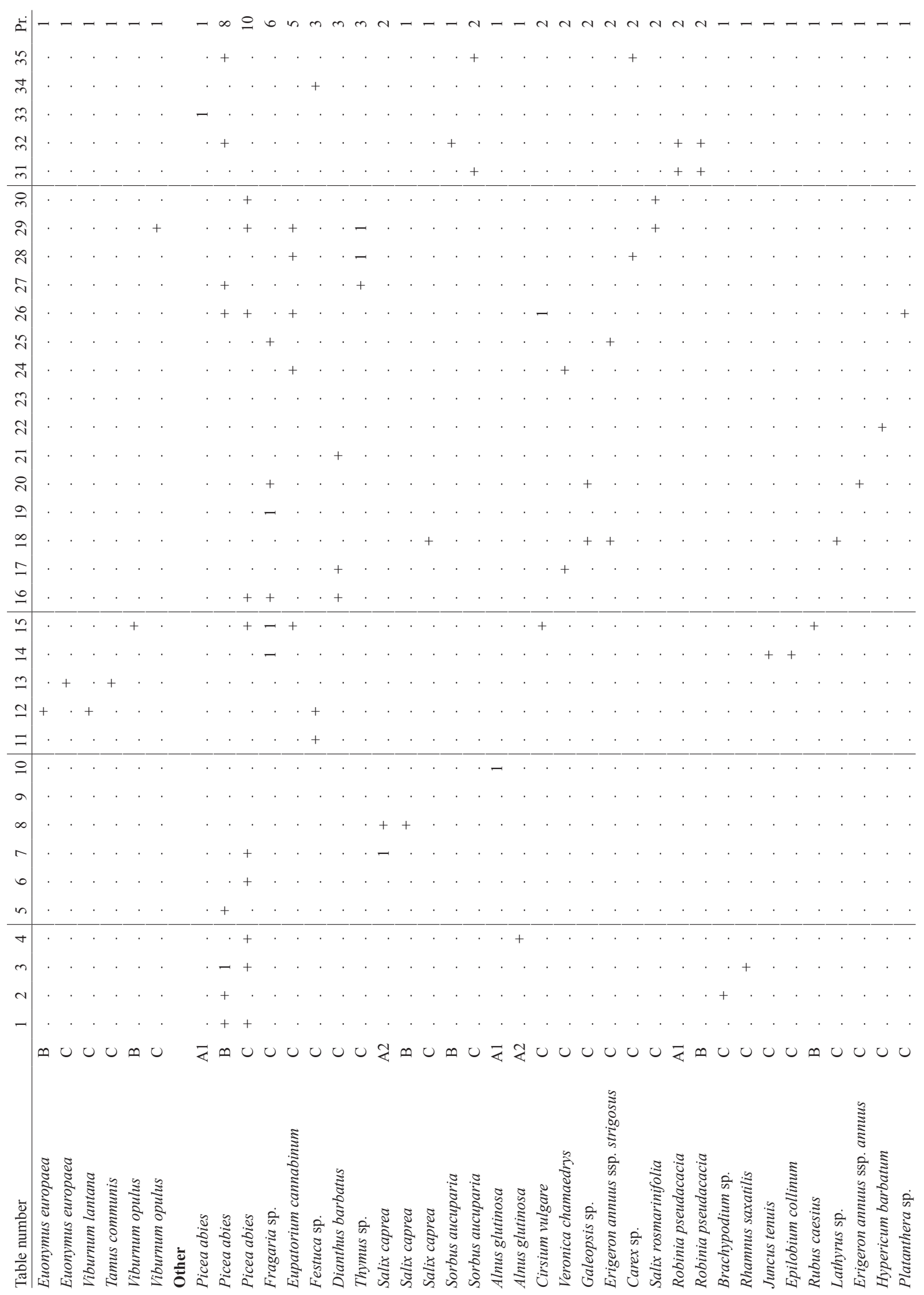



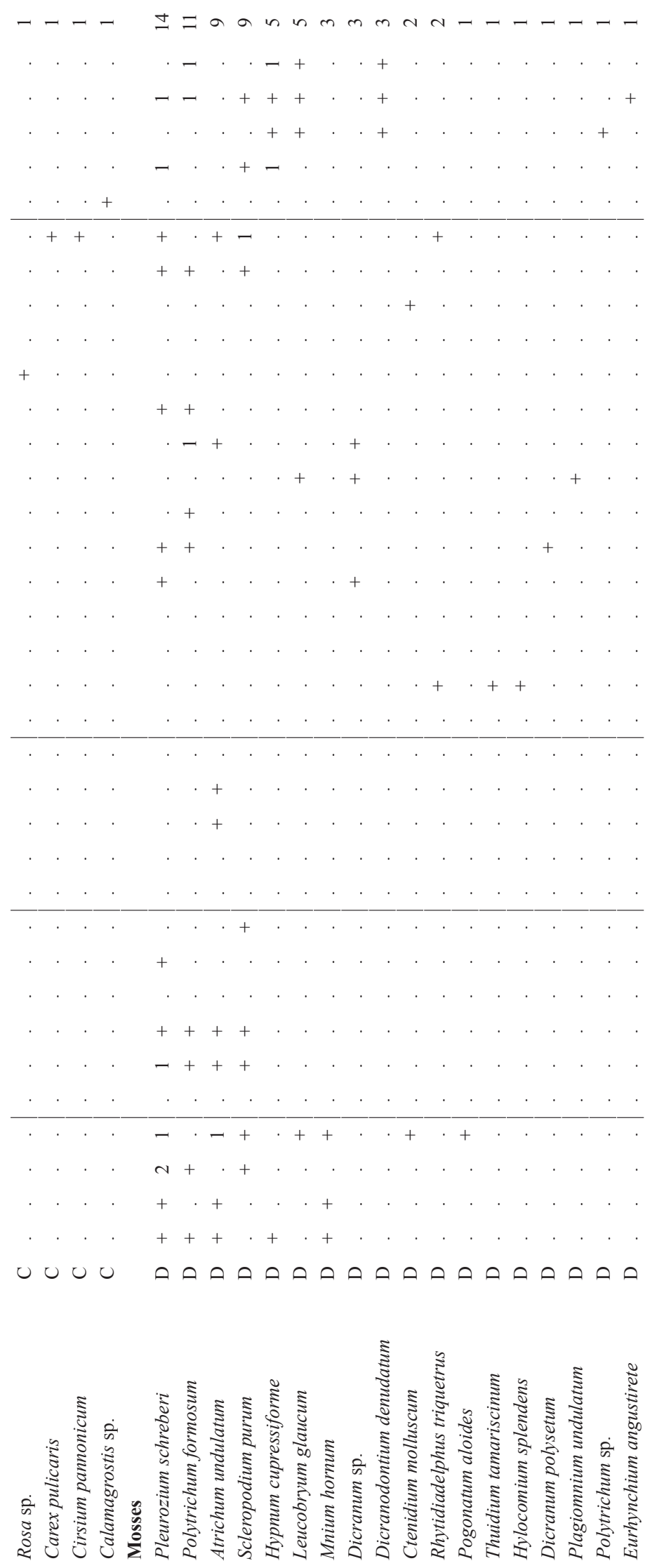
Table 5: Synoptic table of Betula pendula and acidophilous Quercus forests with constancy and median cover. Tabela 5: Sinoptična tabela brezovih in kisloljubnih hrastovih gozdov z prisotnostjo in srednjo pokrovnostjo.

\begin{tabular}{lccccccccccc} 
Group No. & 1 & 2 & 3 & 4 & 5 & 8 & 9 & 10 & 11 & 12 & 13 \\
No. of relevés & 30 & 3 & 4 & 10 & 5 & 3 & - & - & 5 & 15 & 14 \\
\hline
\end{tabular}

Ass. $1 \quad$ Pteridio-Betuletum

\begin{tabular}{|c|c|c|c|c|c|c|c|c|c|c|c|c|c|c|c|c|c|c|c|}
\hline Pteridium aquilinum & $\mathrm{C}$ & 97 & 4 & 3 & 5 & 2 & 2 & 60 & 120 & 3 & 1 & 5 & + & . & 100 & 3 & 87 & 1 & $100^{1}$ \\
\hline Betula pendula & A1 & 97 & 3 & 3 & 5 & 4 & 41 & 100 & 4100 & 3 & 3 & 4 & + & I & +100 & & 20 & 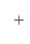 & . \\
\hline Betula pendula & $\mathrm{A} 2$ & 33 & 1 & . & & . & & . & . & & . & & . & . & . & & $\cdot$ & & \\
\hline Betula pendula & B & 43 & + & . & & 1 & 2 & . & . & & 1 & 2 & . & . & 80 & & 7 & 1 & 14 \\
\hline Betula pendula & $\mathrm{C}$ & 57 & + & . & & . & & . & . & & . & & . & . & 20 & + & & & \\
\hline
\end{tabular}

Ass. 2 Populo-Betuletum

Populus tremula

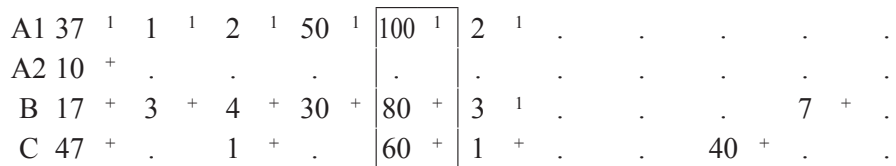

Ass. 3 Deschampsio flexuosae-Quercetum (syn. Betulo-Quercetum)

Populus tremula

Populus tremula

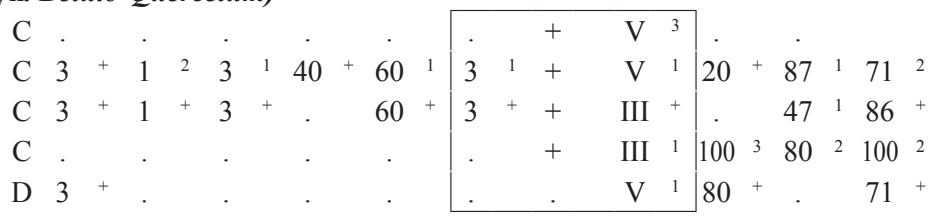

Char. Ass. 4 Luzula luzuloides

Hieracium murorum

diff. Ass. 4 Vaccinium myrtillus

Hypnum cupressiforme

Ass. 4 Molinio-Quercetum

Calamagrostis arundinacea

Molinia caerulea ssp. arundinacea

C. . $30^{+} . \quad$. $\quad \mathrm{I}^{(+)}$

C $50^{2}$

Hieracium racemosum

diff. Erica carnea

Ass. 5 Melampyro-Quercetum

Hieracium sabaudum

C.

C

Chamaecytisus supinus

C 3

C $27^{+}$

Melampyrum pratense ssp. vulgatum

Quercus petraea

Quercus petraea

Quercus petraea

Quercus petraea

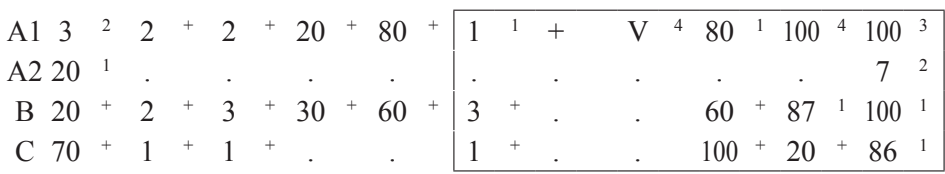

Pteridio-Betuletum Trinajstić \& Šugar ex Rauš \& Matić 1994, Šilc et al. hoc loco

Pteridio-Betuletum Trinajstić \& Šugar ex Rauš \& Matić 1994, Trinajstić (2004)

Pteridio-Betuletum Trinajstić \& Šugar ex Rauš \& Matić 1994, Rauš \& Matić (1994)

Fagetum croaticum boreale abietetosum Horvat 1938 stage Betula pendula, Vukelić \& Španjol (1990)

Populo tremulae-Betuletum pendulae (Glišić) Trinajstić 2004, Trinajstić (2004)

Betulo-Quercetum illyricum Fukarek 1959, Rauš \& Vukelić (1986)

Querco-Betuletum Tüxen 1937 fragm., Horvat (1962)- species listed in text

Deschampsio flexuosae-Quercetum Firbas \& Sigmond 1928, Košir (1994)- shortened synoptic table

Molinio-Quercetum Šugar 1972, Šilc et al. hoc loco

Molinio-Quercetum Šugar 1972, Šugar (1972)

Melampyro-Quercetum praedinaricum Puncer \& Zupančič 1981, Puncer \& Zupančič (1981) 